\title{
TINJAUAN HUKUM KONTRAK SYARIAH TERHADAP KETENTUAN FORCE MAJEURE DALAM HUKUM PERDATA
}

\author{
Oleh: \\ Muhammad Rifqi Hidayat dan Parman Komarudin \\ Fakultas Studi Islam \\ Universitas Islam Kalimantan MAB \\ e-mail: rifqihidayat91@gmail.com dan Parmankomarudinfsi79@gmail.com
}

\begin{abstract}
One of the main differences between conventional and Islamic bank is located on the contract, that the conventional bank uses debt contract with interest which is prohibited in Islam, while Islamic bank only uses contracts that permitted in Islam. In every contract there are a lot of clauses regulating the contract, and one of them is the force majeure clause, which is a respond to a disaster or calamity to prevent unwanted events. Unfortunately, this force majeure clause fully refers to the civil law and conventional contract, and there is no specific rule about it in Islam. Therefore, a deep study is needed to specify about how the economic law of Islam sees the force majeure clause.
\end{abstract}

Keywords: Force Majeure, Civil Law

\begin{abstract}
Abstrak: Salah satu perbedaan utama antara bank konvensional dengan bank syariah terletak pada akadnya, bahwa bank konvensional memakai kontrak hutang dengan bunga yang diharamkan sedangkan bank syariah hanya menggunakan akad-akad yang diperbolehkan oleh Islam. Dalam setiap akad tersebut, terdapat berbagai klausul yang mengatur hal-hal yang berkaitan dengan akad, salah satunya adalah klausul force majeure, yaitu klausul tanggap bencana atau musibah yang bersifat preventif untuk mengantisipasi hal-hal yang tidak diinginkan. Sayangnya, saat ini klausul force majeure tersebut sepenuhnya mengacu kepada hukum perdata dan kontrak konvensional, dan belum ada aturan spesifiknya dalam Islam. Oleh karena itu, perlu ada kajian khusus untuk mengetahui bagaimana tinjauan hukum ekonomi syariah terhadap klausul force majeure tersebut.
\end{abstract}

Kata Kunci: Force Majeure, Hukum Perdata

\section{A. Pendahuluan}

Hubungan

perekonomian

merupakan suatu fitrah dan

kecenderungan alami manusia sebagai makhluk yang memiliki fisik yang terbatas sehingga membuatnya tidak mampu untuk memenuhi segala kebutuhan jasmaniyahnya seorang diri, oleh karena itu ia membutuhkan orang lain melalui berbagai macam transaksi muamalah untuk membantu memenuhi kebutuhan tersebut. Namun tentu saja hubungan 
perekonomian ini harus diatur sedemikian rupa agar manusia terhindar dari transaksi ribawi ataupun garar yang diharamkan. Hal ini disebutkan dalam firman Allah surat al-Baqarah ayat 275 yang berbunyi:

$$
\text { ....... مَأَحَلَّ اللَّهُ الْبَيْعَ وَحَرَّمَ الرِبِّا. }
$$

Artinya :“...Allah telah menghalalkan jual beli dan mengharamkan riba...".

Demi mewujudkan tujuan tersebut, disyariatkanlah berbagai akad muamalah dengan berbagai rukun dan syaratnya, sesuai dengan pemahaman para ulama dari nash alQur'an dan hadis yang tersedia. Secara umum, hukum muamalah diantaranya meliputi permasalahan tentang siapa saja yang boleh melakukan transaksi, benda apa saja yang halal untuk ditransaksikan, bagaimana bentuk pembuktian kesepakatan antara kedua belah pihak, dan lain sebagainya. ${ }^{1}$

Salah satu akad muamalah yang sering dipraktekkan di wilayah perbankan adalah akad Murabahah. Produk ini dilaksanakan dengan prinsip jual beli. Pada akad jual beli

\footnotetext{
1 Rachmat Syafe'i, Fiqih Muamalah, (Bandung: Pustaka Setia, 2001), hal 45.
}

bank syariah akan memperoleh pendapatan secara pasti. Akad dengan kepastian pendapatan ini sering disebut dengan istilah Natural Certainty Contracts, yaitu kontrak dalam bisnis yang memberikan kepastian pembayaran baik dari segi jumlah maupun waktu. Ciri natural certainty contract tersebut pertama yaitu kepastian Cash Flow yang sudah disepakati di awal kontrak, dan kepastian dalam hal obyek pertukarannya secara jumlah, mutu, waktu maupun harganya. ${ }^{2}$

Perbankan syariah cenderung lebih menyukai penggunaan produk murabahah dengan sistem margin keuntungan ketimbang menggunakan produk syirkah dengan sistem bagi hasil karena sistem bagi hasil lebih sulit untuk diterapkan, penuh dengan risiko dan ketidak pastian.

Dalam setiap kontrak murabahah sebagaimana dipraktekkan di Bank Syariah, terdapat berbagai klausul yang mendampingi akad tersebut untuk memberikan kepastian hukum bagi kedua belah pihak. Salah satu klausul yang dicantumkan adalah

\footnotetext{
${ }^{2}$ Muhamad, Teknik Perbitungan Bagi Hasil dan Pricing di Bank Syariah , (Yogyakarta: UII Press, 2012), hal 151.
} 
mengenai force majeure. Salah satu contoh klausul tersebut misalnya dalam form akad murabahah milik Bank Muamalat. Dalam pasal 22 akad tersebut disebutkan:

\section{Pasal 22}

\section{FORCE MAJEURE}

1. Keadaan Kahar (Force Majeure) yaitu peristiwa-peristiwa yang disebabkan oleh bencana alam, kerusuhan, huru-hara, pemberontakan, epidemi, sabotase, peperangan, pemogokan, kebijakan pemerintah atau sebab lain diluar kekuasaan NASABAH dan BANK.

2. Dalam hal terjadi Keadaan Kahar (Force Majeure), maka Pihak yang terkena akibat langsung dari Keadaan Kahar (Force Majeure) tersebut wajib memberitahukan secara tertulis dengan melampirkan bukti-bukti dari Kepolisian/Instansi yang berwenang kepada Pihak lainnya mengenai peristiwa Keadaan Kahar (Force Majeure) tersebut dalam waktu selambat-lambatnya 14 (empat belas) hari Kerja terhitung sejak tanggal Keadaan Kahar (Force Majeure) ditetapkan.

3. Keterlambatan atau kelalaian Para Pihak untuk memberitahukan adanya Keadaan Kahar (Force Majeure) tersebut mengakibatkan tidak diakuinya peristiwa tersebut sebagai Keadaan Kahar (Force Majeure) oleh Pihak lain

4. Segala dan tiap-tiap permasalahan yang timbul akibat terjadinya Keadaan Kahar (Force
Majeure) akan diselesaikan oleh NASABAH dan BANK secara musyawarah untuk mufakat. Hal tersebut tanpa mengurangi hakhak BANK sebagaimana diatur dalam Akad ini.

Force Majeure (overmacht) atau yang sering diterjemahkan sebagai "keadaan memaksa" merupakan keadaan terpaksa yang menyebabkan seseorang tidak wajib melakukan perbuatan yang wajib dilakukan dalam keadaan yang normal. ${ }^{3}$ Keadaan ini membuat seorang debitur terhalang untuk melaksanakan prestasinya karena keadaan atau peristiwa yang tidak terduga pada saat dibuatnya kontrak, keadaan atau peristiwa tersebut tidak dapat dipertanggungjawabkan kepada debitur karena ia tidak dapat dikatakan lalai ataupun melakukan wanprestasi. ${ }^{4}$

Ketentuan mengenai force majeure tersebut ada pada pasal 1244 dan 1245 KUH Perdata yaitu: ${ }^{5}$

\section{Pasal 1244}

3 Ibnu Sina Chandranegara, Pengujian PERPPU terkait Sengketa Kewenangan Konstitusional Antar-Lembaga Negara, dalam Jurnal Yudisial Vol. V No. 1, April 2012, hal 12.

${ }^{4}$ Michael R. Purba, Kamus Hukum, (Jakarta: Widyatamma, 2009), hal 308.

${ }^{5}$ Kitab Undang-Undang Hukum Perdata, Terj. Soesilo dan Pramuji R., (Rhedbook Publisher, 2008), hal 286. 
Jika ada alasan untuk itu, si berhutang harus dihukum mengganti biaya, rugi, dan bunga apabila ia tak dapat membuktikan, bahwa hal tidak atau tidak pada waktu yang tepat dilaksanakannya perikatan itu disebabkan suatu hal yang tak terduga, pun tak dapat dipertanggungkan kepadanya, kesemuanya itu pun jika itikad buruk tidaklah ada pada pihaknya.

\section{Pasal 1245}

Tidaklah biaya rugi dan bunga, harus digantinya, apabila dikarenakan keadaan memaksa atau karena suatu kejadian tak disengaja si berhutang berhalangan memberikan atau berbuat sesuatu yang diwajibkan, atau dikarenakan hal-hal yang sama telah melakukan perbuatan yang dilarang.

Sementara itu, dalam peraturan perundangan mengenai ekonomi syariah di Indonesia, termasuk dalam fatwa DSN-MUI sekalipun, masih belum ada aturan spesifik yang mengatur mengenai force majeure sebagaimana yang dimaksudkan dalam hukum perdata. Namun dalam fiqh klasik, ditemukan salah satu teori yang mendekati hal tersebut, yaitu ketentuan al-Jawa'ih dalam akad salam.

Oleh karena itu, perlu dilakukan kajian secara mendalam mengenai force majeure tersebut teori dalam fiqh klasik di atas, sebagai dasar untuk mengqiyaskan dan melegalisasi force majeure dalam perspektif hukum ekonomi syariah.

\section{B. Force Majeure dalam Hukum Perdata}

Force Majeure (keadaan memaksa) adalah suatu keadaan yang tidak dapat diduga sebelumnya sehingga memaksa seorang debitur untuk terhalang dari memenuhi prestasi yang dibebankan kepadanya. Peristiwa tersebut dapat berupa hal yang menimpa pribadi debitur itu sendiri (force majeure subjektif) misalnya debitur ditimpa penyakit yang sangat berat sehingga tidak dapat berprestasi lagi, atau yang merusak dan atau memusnahkan objek kontrak yang dimaksudkan (force majeure objektif). Maka dalam hal ini, debitur tidak dapat dianggap wanprestasi dan tidak dapat dituntut membayar ganti rugi selama debitur tersebut tidak dalam keadaan beritikad buruk. ${ }^{6}$ Lebih spesifik lagi, dalam KUH Perdata pasal 1244, 1245, dan 1545 disebutkan:

\section{Pasal 1244}

Debitur harus dihukum untuk mengganti biaya, kerugian dan bunga, bila dia tidak dapat membuktikan bahwa tidak dilaksanakannya perikatan itu atau tidak tepat waktu dalam melaksanakan perikatan itu

\footnotetext{
${ }^{6}$ Munir Fuady, Hukum Kontrak dari Sudut Pandang Hukum Bisnis, (Bandung: Citra Aditya Bakti, 2007), hal 113.
} 
disebabkan oleh suatu hal yang tidak terduga, yang tidak dapat dipertanggungjawabkan kepadanya, walaupun tidak ada iktikad buruk padanya.

\section{Pasal 1245}

Tidak ada pergantian biaya, kerugian dan bunga, bila dalam keadaan memaksa atau karena hal yang terjadi scara kebetulan, debitur terhalang untuk memberikan atau berbuat sesuatu yang diwajibkan, atau melaksanakan suatu perbuatan yang terlarang baginya.

\section{Pasal 1545}

Jika barang tertentu, yang telah dijanjikan untuk ditukar musnah di luar kesalahan pemiliknya, maka persetujuan dianggap gugur dan pihak yang telah memenuhi persetujuan dapat menuntut kembali barang yang telah ia berikan dalam tukar-menukar.

Berdasarkan ketiga pasal diatas, dapat dipahami bahwa secara umum ada tiga syarat diakuinya suatu peristiwa sebagai force majeure, yaitu:

1. Peristiwa yang menyebabkan terjadinya force majeure tersebut tidak diduga sebelumnya oleh para pihak.

2. Peristiwa yang menyebabkan terjadinya force majeure tersebut terjadi diluar kesalahan para pihak.

3. Para pihak tidak dalam keadaan beriktikad buruk. apabila ketiga syarat force majeure diatas telah terpenuhi, maka secara prinsip debitur tidak dapat dianggap wanprestasi karena gagal melaksanakan kontraknya.

Jika dilihat dari segi kemungkinan pelaksanaan prestasi dalam kontrak, Force Majeure dapat diklasifikasikan menjadi dua jenis, yaitu: $^{7}$

1. Force majeure absolut. sebuah force majeure dikatakan bersifat absolut jika sampai kapanpun suatu prestasi yang terbit dari kontrak tidak mungkin dilakukan lagi. Misalnya jika barang yang merupakan objek dari kontrak tersebut telah musnah akibat terbakar diluar kesalahan debitur.

2. Force majeure relatif. maksudnya yaitu suatu force majeure dimana pemenuhan prestasi secara normal tidak mungkin dilakukan, walaupun jika dipaksakan masih mungkin dilakukan. Misalnya terhadap kontrak impor-expor dimana setelah kontrak dibuat terdapat larangan impor atas barang itu. 
Dalam hal ini barang tersebut tidak mungkin lagi diserahkan (diimpor), walaupun sebenarnya masih dapat dikirim melalui jalan penyeludupan misalnya. Dalam hal ini dapat dikatakan bahwa kontrak masih mungkin dilaksanakan, tetapi sudah tidak praktis lagi. Hal ini juga biasa disebut dengan istilah impracticability (ketidakpraktisan).

\section{Teori al-Jawa'ih dalam Hukum Islam}

Teori al-Jawa'ih terdapat dalam akad Jual beli salam. Akad salam adalah transaksi jual-beli barang tertentu antara pihak penjual dan pembeli sebesar harga pokok ditambah nilai keuntungan yang disepakati, dimana waktu penyerahan barang dilakukan di kemudian hari sementara penyerahan uang dibayarkan dimuka (secara tunai). ${ }^{8}$ Dalam hal apabila komoditas yang ditransaksikan berupa buah ataupun hasil pertanian lainnya, apabila buah dan hasil pertanian tersebut sudah terlihat matangnya maka sudah boleh diperjual-belikan dengan sistem salam,

8 Muh. Fudhail Rahman, Bai' Salam dalam Transaksi Muamalat, dalam Jurnal al-Risalah Vol. 13 No. 1, Mei 2013, hal 38. dimana pembeli membayar terlebih dahulu sedangkan barang diserahkan penjual setelah ia menjadi matang sempurna.

Namun, apabila pada masa pematangan tersebut terjadi bencana (ja'ihab) di luar kekuasaan kedua belah pihak sehingga buah ataupun hasil pertanian yang diperjualbelikan menjadi rusak sebagian ataupun keseluruhan, maka kerugian akan ditanggung oleh penjual. ${ }^{9}$ Ketentuan tentang al-Jawaỉh ini didasarkan kepada hadis yang berbunyi:

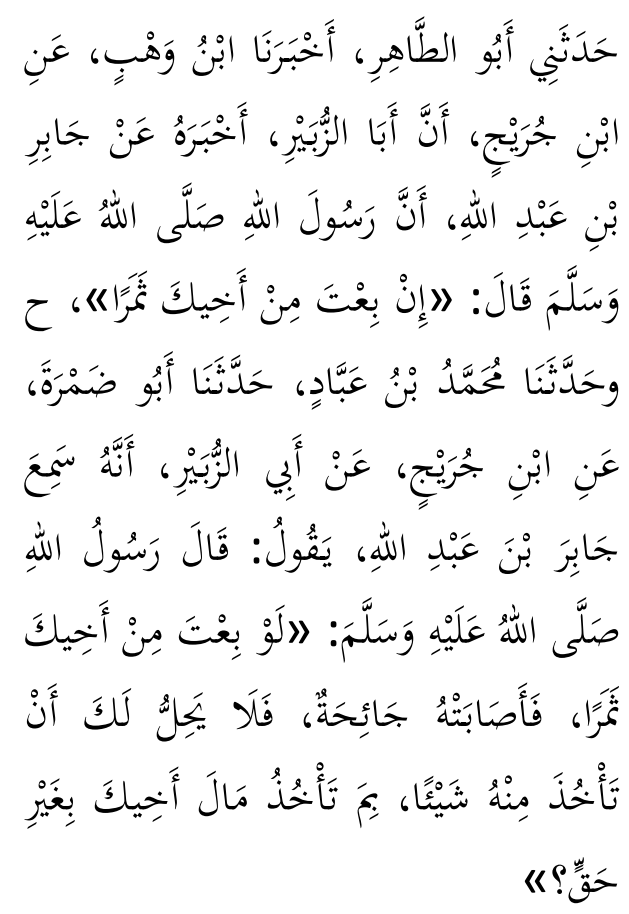

Artinya :" Jika engkau menjual buah kepada saudaramu, lalu terkena bencana, maka tidak balal bagimu mengambil

${ }^{9}$ Sayyid Sabiq, Fiqh Sunnah Juz 3, (Kairo: Dar al-Fath, 1999), hal 109. 
sesuatu pun darinya. Dengan (imbalan) apa engkau mengambil harta saudaramu dengan tanpa bak?" 10

Berdasarkan teori tentang alJawa'ih tersebut, maka dapat terlihat kontradiksi diantara keduanya. Yaitu bahwa dalam al-Jawa'ih, penjual selaku debitur lah yang bertanggung jawab, kewajiban pembeli hanyalah membayar harga yang telah dikurangi dari akad awal sesuai dengan kerusakan yang terjadi pada objek akibat bencana tersebut. ${ }^{11}$ Sedangkan dalam Force Majeure, sebagaimana yang disebutkan dalam pasal 1244 dan 1245 KUH Perdata, debitur tidak dapat dimintai pertanggung jawaban dan tidak dapat dianggap wanprestasi. Kewajiban debitur untuk menunaikan prestasi telah gugur sehingga kreditur tidak berhak lagi menuntutnya. ${ }^{12}$

\section{Tinjauan Hukum Kontrak Syariah} Terhadap Ketentuan Force Majeure dalam Hukum Perdata

Salah satu prinsip utama dalam muamalah adalah prinsip kebebasan. Hal ini sesuai dengan petunjuk

10 Imam Muslim, Sabih Muslim, Juz III, (Beirut: Dar al-Fikr, 2008), hal 1190.

11 Syamsul Anwar, Hukum Perjanjian Syariah, (Jakarta: PT Raja Grafindo Persada, 2007), hal 327.

12 Rahmat S.S. Soemadipradja, Penjelasan Hukum Tentang Keadaan Memaksa, (Jakarta: National Legal Reform Program, 2010), hal 51.
Rasulullah bahwa segala bentuk perjanjian muamalah hukumnya adalah mubah atau diperbolehkan, asalkan transaksi tersebut tidak menghalalkan yang haram ataupun sebaliknya. Dengan kata lain, selama perjanjian itu tidak dilarang baik dalam al-Qur'an maupun hadis, maka ia dapat dipandang sebagai suatu perjanjian yang sah menurut kacamata Islam. Mengenai hal ini Rasulullah bersabda:

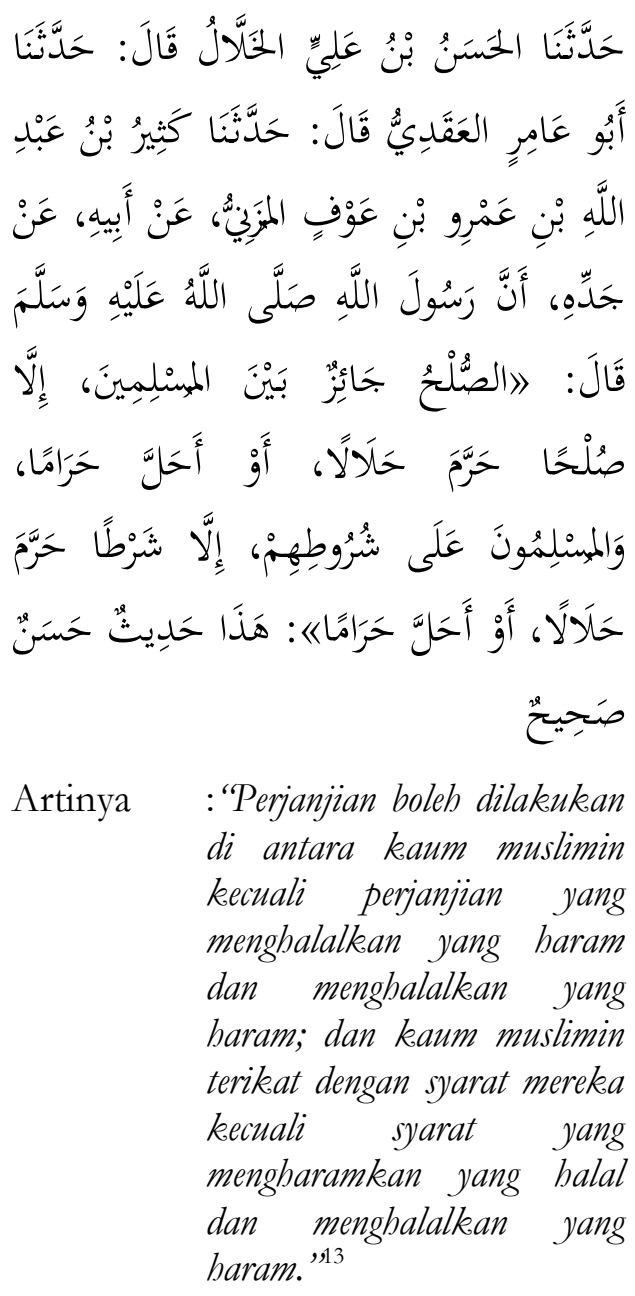

Artinya :"Perjanjian boleh dilakukan di antara kaum muslimin kecuali perjanjian yang menghalalkan yang haram dan menghalalkan yang baram; dan kaum muslimin terikat dengan syarat mereka kecuali syarat yang mengharamkan yang halal dan menghalalkan yang haram." $" 13$

13 At-Tirmizi, Sunan At-Tirmizi, Juz III, (Beirut: Dar Al-Garbi Al-Islami, 1998), hal 626. 
Berdasarkan hadis tersebut maka para ulama merumuskan kaidah penting yang menjadi acuan dalam pembentukan dan legalisasi berbagai akad yang dipraktekkan selama ini, yaitu:

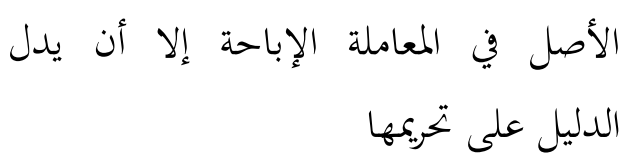

Artinya :"Hukum asal dalam semua bentuk muamalah adalab boleh dilakukan kecuali ada dalil yang mengharamkannya."14

Kaidah di atas mengindikasikan bahwa semua bentuk transaksi muamalah pada dasarnya diperbolehkan, baik transaksi tersebut berupa akad tradisional yang telah dirumuskan di masa Rasulullah dan ulama salaf, ataupun ia merupakan kontrak kontemporer seperti IMBT yang baru-baru ini digagas, kecuali yang dalam Syariat diharamkan secara tegas seperti mengakibatkan kemudaratan, ada unsur penipuan, judi, maupun riba. ${ }^{15}$

Berkaitan dengan Force Majeure, kaidah ini merupakan poin terpenting yang dapat menjadi dasar diperbolehkannya pencantuman Force

14 A. Djazuli, Kaidah-Kaidah Fikih, Jakarta: Kencana, 2010), hal 130.

${ }^{15}$ Ibid
Majeure tersebut dalam akad. Sebab tidak ada satupun nas yang melarang suatu bentuk perjanjian yang mensyaratkan hal-hal tertentu sebagai tindakan preventif apabila terjadi bencana yang sama sekali tidak diinginkan dan tidak diduga oleh kedua belah pihak sebagaimana yang dimaksudkan dalam klausul Force Majeure.

Lebih jauh lagi, Force Majeure merupakan keadaan darurat sekaligus menyulitkan sehingga dapat dikaitkan dengan kaidah yang lebih khusus lagi, sebagaimana dalil yang dipakai oleh teori keadaan yang memberatkan (masyaqqab) dalam hukum Islam. Dasar hukum dari konsep keadaan yang memberatkan ini adalah kaidah fikih sebagai berikut:

$$
\begin{gathered}
\text { الضرر يزال } \\
\text { Artinya }
\end{gathered}
$$

Artinya : "Kesukaran mendatangkan kelonggaran."

Karakterisitik Force Majeure yang merupakan suatu bencana atau musibah adalah sebuah keadaan darurat yang secara hukum akan berimplikasi kepada munculnya berbagai aturan untuk menghilangkan 
ataupun setidaknya mengurangi kondisi darurat tersebut. Seorang pengusaha misalnya dilarang keras untuk menimbun kebutuhan makanan pokok karena tindakan tersebut dapat menimbulkan kemudaratan yang besar bagi masyarakat. Begitu pula dalam hal Force Majeure ini misalnya, seorang kreditur tidak layak membebankan debitur yang tertimpa musibah berat dengan beban yang sama saat debitur belum mengalami musibah itu. Bahkan jika dianggap perlu, kontrak dapat dibatalkan untuk menghilangkan beban tambahan bagi debitur dalam keadaan darurat tersebut. Kaidah pertama ini cocok digunakan pada Force Majeure kategori absolut dimana kontrak tidak mungkin dilanjutkan kembali.

Sementara itu, untuk Force Majeure kategori relatif, dimana pelaksanaan isi kontrak sebenarnya masih dapat dilakukan walaupun akan sangat menyulitkan, maka dalam hal ini kaidah kedua lah yang lebih tepat. Makna kaidah tersebut adalah bahwa jika terjadi suatu kondisi yang menyulitkan dimana pelaksanaan sebuah hukum lebih berat dan menyulitkan dibandingkan kebiasaan, maka syariah akan memberikan keringanan sehingga seorang mukalaf dapat melaksanakan hukum tersebut tanpa kesukaran. Misalnya seorang muslim yang sedang dalam perjalanan boleh melaksanakan salat dengan cara qasar atau jamak. Adapun dalam hal Force Majeure ini misalnya, jika terjadi suatu hal yang menyebabkan debitur kesulitan memenuhi prestasi sebagaimana biasanya, maka harus ada keringanan semacam perpanjangan jangka waktu atau yang sejenisnya.

Dengan demikian, dapat disimpulkan bahwa Force Majeure dipandang dari perspektif kaidah fikih telah memenuhi nilai-nilai yang diinginkan dalam kaidah-kaidah tersebut.

Selain itu, force majeure juga dapat dianalisis melalui perspektif Maqashid Syariah. Hal ini dikarenakan salah satu kebutuhan pokok (dharuriyyat) sebagaimana yang dikonsepkan oleh Syatibi adalah bifzul maal, ${ }^{16}$ yaitu bahwa perlindungan terhadap harta merupakan kebutuhan pokok manusia. Namun dalam hal harta tersebut manusia dibatasi dalam

16 Satria Effendi dan M. Zein, Ushul Fiqh, (Jakarta: Kencana, 2009), hal 233. 
tiga syarat, yaitu harta harus dikumpulkan dengan cara yang halal, dipergunakan untuk hal-hal yang halal, dan dari harta ini harus dikeluarkan hak Allah dan masyarakat tempat dia hidup berupa zakat.

Prinsip penjagaan kepada harta ini kemudian diperluas oleh para ulama, yaitu agar harta tidak hanya terjaga dari tangan-tangan jahil semata, tapi juga dapat terlindung dari kemungkinan-kemungkinan buruk yang diakibatkan oleh alam maupun kecelakaan-kecelakaan yang tidak diinginkan. Dari sinilah muncul suatu akad yang dinamakan asuransi atau atTa'min.

Asuransi berasal dari bahasa Inggris insurance yang sering diterjemahkan dalam bahasa Indonesia dengan jaminan atau pertanggungan. Sedangkan dalam bahasa Arab, asuransi disebut dengan istilah at-Ta'min yang berarti memberi keamanan, ketenangan, dan perlindungan, sehingga pihak yang dilindungi terbebas dari rasa takut. ${ }^{17}$

Adapun secara istilah, dalam dalam Kitab Undang-Undang Hukum Perniagaan atau Wetboek van

17 Nur Rianto al-Arif, Lembaga Kenangan Syariah, (Bandung: Pustaka Setia, 2012), hal 214.
Koophandel disebutkan bahwa Asuransi atau pertanggungan adalah suatu perjanjian, dengan mana seorang penanggung mengikatkan diri kepada seorang tertanggung, dengan menerima suatu premi, untuk memberikan penggantian kepadanya karena suatu kerugian, kerusakan atau kehilangan keuntungan yang diharapkan, yang mungkin akan dideritanya karena suatu peristiwa yang tak menentu. ${ }^{18}$ Sedangkan dalam konsep Syariah, asuransi dilaksanakan dengan sistem takaful (saling menanggung) dimana sekumpulan pihak bekerjasama dalam usaha untuk saling melindungi dan tolong menolong melalui investasi yang memberikan pola pengembalian untuk menghadapi resiko-resiko tertentu yang barangkali terjadi di masa yang akan datang. ${ }^{19}$ Dalam hal ini Allah mengingatkan umat Islam untuk selalu bersiap menghadapi apapun yang terjadi di masa depan, yaitu dalam surah al-Hasyr ayat 18 yang berbunyi:

18 Kitab Undang-Undang Hukum Dagang, pasal 246.

19 Nur Rianto al-Arif, Lembaga Kenangan Syariah, hal 214. 


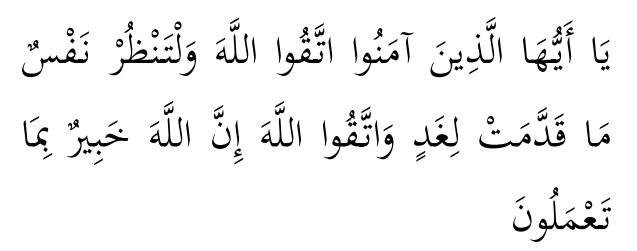

Artinya :" Hai orang-orang yang beriman, bertakwalah kepada Allab dan bendaklab setiap diri memperhatikan apa yang telah diperbuatnya untuk hari esok; dan bertakwalah kepada Allah, sesunggubnya Allah Maha Mengetabui apa yang kamu kerjakan.”

Bentuk pengamanan tambahan terhadap harta melalui asuransi syariah di atas dapat dikategorikan sebagai kebutuhan sekunder atau hajiyyat, yaitu kebutuhan yang apabila tidak terpenuhi maka keselamatan manusia tidak sampai terancam, namun ia akan mengalami kesulitan. Islam berkeinginan untuk menghilangkan segala kesulitan tersebut, sebagaimana diperbolehkannya qasar dan jamak dalam salat saat berada dalam perjalanan, serta diperbolehkannya tidak berpuasa ramadan bagi ibu hamil atau menyusui. ${ }^{20}$ Demikian pula yang dimaksudkan dalam asuransi, yaitu untuk meringankan beban kerugian harta yang diasuransikan apabila terjadi hal tak terduga yang tidak diharapkan di masa depan.

${ }^{20}$ Satria Effendi dan M. Zein, Ushul Fiqh, 235
Force Majeure, yang merupakan bagian dari akad berupa suatu bentuk perjanjian preventif apabila terjadi keadaan yang tidak diinginkan, juga memiliki ruh serta tujuan yang similar dengan asuransi. Yaitu bagaimana agar pihak nasabah mendapatkan keringanan di tengah kesulitannya.

Dengan demikian dapat ditarik kesimpulan bahwa pencantuman Force Majeure dalam sebuah akad memiliki maslahat yang sangat besar, dan setidaknya berada pada tingkatan hajiyat (sekunder), dimana klausul keadaan memaksa tersebut memberikan perlindungan baik kepada pihak nasabah maupun pihak bank saat terjadi peristiwa yang tidak diinginkan

Terakhir, apabila force majeure tersebut dilihat melalui kacamata fiqh klasik, terdapat sebuah pembahasan yang cukup mendekati ketentuan mengenai force majeure sebagaimana yang dimaksudkan dalam hukum perdata, yaitu al-Jawa'ih.

Persamaan tersebut terlihat pada proses terjadinya force majeure dan al-Jawa'ih yang dilatarbelakangi adanya peristiwa tak terduga. Force majeure sebagaimana yang disebutkan dalam akad dapat disebabkan oleh 
kebakaran, bencana alam, peperangan, aksi militer, huru-hara, malapetaka, pemogokan, epidemi, dan kebijaksanaan maupun peraturan Pemerintah atau penguasa setempat yang secara langsung dapat mempengaruhi pemenuhan pelaksanaan perjanjian. Sementara itu al-Jawa'ih bisa terjadi akibat banjir atau kekeringan yang secara langsung mempengaruhi hasil pertanian atau perkebunan yang menjadi objek transaksi

Sebaliknya, dalam hal akibat hukumnya, terdapat perbedaan yang sangat esensial antara keduanya. Jika mengacu pada hadis yang menjadi dasar dari al-Jawa'ih tersebut, maka dapat ditarik kesimpulan bahwa penjual sebagai debitur secara mutlak memikul kerugian, ia tidak berhak atas biaya yang telah dibayarkan oleh pembeli dan harus mengembalikannya, walaupun banjir ataupun kekeringan merupakan hal tak tertuga yang terjadi di luar kuasanya. Sedangkan dalam force majeure, Yahya Harahap menjelaskan bahwa akibat hukumnya adalah sebagai berikut: ${ }^{21}$

21 Rahmat S.S. Soemadipradja, Penjelasan Hukum tentang Keadaan Memaksa, hal 12.
1. Membebaskan debitur dari membayar ganti rugi. Dalam hal ini, hak kreditur untuk menuntut gugur untuk selama-lamanya. Jadi, pembebasan ganti rugi sebagai akibat keadaan memaksa adalah pembebasan mutlak.

2. Membebaskan debitur dari kewajiban melakukan pemenuhan prestasi yang diakibatkan keadaan memaksa relatif. Pembebasan itu pada umumnya hanya bersifat menunda, selama keadaan force majeure masih menghalangi/merintangi debitur melakukan pemenuhan prestasi. Bila keadaan memaksa hilang, kreditur kembali dapat menuntut pemenuhan prestasi. Pemenuhan prestasi tidak gugur selamalamanya, hanya tertunda, sementara keadaan memaksa masih ada.

Singkatnya, force majeure pada dasarnya memiliki dua akibat hukum, yaitu pembebasan ganti rugi dan penundaan pemenuhan prestasi kepada pihak debitur yang mengalami musibah. Sedangkan al-Jawa'ih cenderung lebih hati-hati dalam hal ini, dimana debitur tetap diharuskan 
untuk mengembalikan biaya yang telah dibayarkan oleh kreditur jika ia tidak mampu memenuhi prestasi yang telah dijanjikan. Sebab dalam Islam, sebagaimana yang termaktub dalam surah an-Nisa ayat 29 bahwa mengambil harta orang lain tanpa hak sangat dilarang, termasuk dalam keadaan sulit sekalipun.

Walaupun demikian, dalam hal akibat hukum tersebut ada satu poin yang dapat menjadi titik temu antara keduanya, yaitu bahwa dalam alJawa'ih tidak terdapat larangan untuk menunda pemenuhan prestasi. Perlu digarisbawahi bahwa hak kreditur dalam force majeure sama sekali tidak dihilangkan, hanya saja jangka waktu pemenuhan hak tersebut diperpanjang untuk memberi kolonggaran bagi pihak debitur. Sedangkan dalam al-Jawa'ih akad dianggap selesai karena debitur tidak dapat memenuhi prestasi sesuai pada waktu yang dijanjikan akibat bencana yang menimpanya, tanpa ada opsi penundaan, walaupun sebenarnya tidak terdapat larangan untuk melakukan penundaan tersebut.

Oleh karena itu, dapat disimpulkan bahwa force majeure memiliki kesamaan hukum dengan al-
Jawa'ih yang akibat hukumnya ditambah dengan opsi penundaan pemenuhan prestasi.

Selain kesamaan dalam aspek praktis di atas, baik force majeure maupun al-Jawa'ih juga memiliki tujuan dan nilai yang seragam. Keduanya berperan sebagai sebuah solusi, dan sekaligus merupakan kepastian serta perlindungan hukum bagi debitur dan kreditur dalam menghadapi situasi tak tertuga yang menghalangi berjalannya kontrak sebagaimana mestinya.

Berdasarkan ketiga analisis di atas, baik dari sisi kaidah fikih, Maqasid Syariah, maupun fikih, dapat disimpulkan bahwa pencantuman klausul force majeure dalam akadakad syariah merupakan hal yang diperbolehkan dalam Islam, dan bahkan sangat diperlukan sebagai bentuk perlindungan hukum bagi kedua belah pihak.

\section{E. Kesimpulan dan Saran}

Konsep force majeure yang merupakan keadaan darurat/memberatkan sebagaimana diinginkan dalam hukum perdata jika dilihat dari perspektif kaidah fikih, maqasid syariah, dan fikih, memiliki 
nilai-nilai yang sejalan dengan apa yang dikehendaki dalam Islam, terutama dengan teori masyaqqah atau keadaan yang memberatkan. Maka pencantumannya dalam akad boleh dilakukan.

Oleh karena itu, disarankan kepada perbankan syariah untuk mencantumkan klausul force majeure dalam akad selengkap-lengkapnya dan seadil-adilnya antara kepentingan pihak bank dan nasabah sehingga tidak berat sebelah.

\section{Daftar Pustaka}

A. Djazuli, 2010, Kaidah-Kaidah Fikih, Jakarta: Kencana.

At-Tirmizi, 1998, Sunan At-Tirmizi, Beirut: Dar Al-Garbi Al-Islami.

Imam Muslim, 2008, Sabih Muslim, Beirut: Dar al-Fikr.

Michael R. Purba, 2009, Kamus Hukum, Jakarta: Widyatamma.

Muhamad, 2012, Teknik Perbitungan Bagi Hasil dan Pricing di Bank Syariah, Yogyakarta: UII Press.

Munir Fuady, 2007, Hukum Kontrak dari Sudut Pandang bukum Bisnis, Bandung: Citra Aditya Bakti.
Nur Rianto al-Arif, 2012, Lembaga Keuangan Syariah, Bandung: Pustaka Setia.

Rachmat Syafe'i, 2001, Fiqih Muamalah, Bandung: Pustaka Setia.

Rahmat S.S. Soemadipradja, 2010, Penjelasan Hukum Tentang Keadaan Memaksa, Jakarta: National Legal Reform Program.

Satria Effendi dan M. Zein, 2009, Ushul Fiqh, Jakarta: Kencana.

Sayyid Sabiq, 1999, Figh Sunnah, Kairo: Dar al-Fath.

Syamsul Anwar, 2007, Hukum Perjanjian Syariah, Jakarta: PT Raja Grafindo Persada.

Ibnu Sina Chandranegara, Pengujian PERPPU terkait Sengketa Kewenangan Konstitusional Antar-Lembaga Negara, Jurnal Yudisial Vol. V No. 1, April 2012.

Muh. Fudhail Rahman, Bai' Salam dalam Transaksi Muamalat, Jurnal al-Risalah Vol. 13 No. 1, Mei 2013.

Kitab Undang-Undang Hukum Dagang

Kitab Undang-Undang Hukum Perdata 